\title{
I Saw Ramallah
}

Mourid Barghouti, Ahdaf Soueif (translator). American University in Cairo Press, 2001. 184 pages.

I Saw Ramallah is about Barghouti's much-awaited journey to his homeland after thirty years of exile. The book is rich with personal memories of places, people, towns, events and times both in the past and present and is full of humor, laughter, joy, sadness, heartbreak, sacrifice and mouming. Throughout the book, there is a haunting feeling of loss and loneliness as a result of dispossession.

The book starts at the bridge between Jordan and Palestine, the very bridge that Barghouti had innocently crossed thirty years ago in order to reach Cairo to continue his studies. When war broke out in 1967 , he was still in Cairo and could not retum. He remembers that day in 1967 very vividly, since it was to mark the beginning of a new life for him, as all of a sudden he was "struck by displacement." One wonders if he would have remembered the details as intensely were it just another day in his normal life and not a day that would mark the beginning of life as an exile.

Barghouti jumps from his present to the past and back, cleverly and smoothly, revealing a little here and there, and beckoning the reader to hasten eagerly through the pages to discover the rest of the story. After a 
long wait at the Jordanian side, he is finally allowed to cross the bridge to enter Palestine, the land of his dreams and subject of many of his poems. Crossing the bridge invokes more emotions in him than actually standing on Palestinian soil for the first time in thirty years. He strikes a silent conversation with this "short and unimportant bridge." He wonders how such an insignificant thing could wield so much power to separate nations and families since it was not made by "volcanoes and their thick orange terror," but by "miserable carpenters, who held their nails in the corners of their mouths, and their cigarettes behind their ears." When he finally reaches Palestine, he seems lost, not knowing what he is returning as: "A visitor? A refugee? A citizen? A guest?" This confused feeling continues and intensifies, as no one seems to give him any extra attention. To him, being back in Palestine is a tremendous moment after thirty years of waiting and hoping, but to all around him, he is just one of thousands. He is soon reunited with some of his family members, with whom he stays while in Ramallah. Memories of familiar streets and favorite hangouts come flooding back to him. But with the enjoyment of being back comes the realization that he cannot escape the politics of the place, in the form of settlements, checkpoints and the shining guns of the young, bored Israeli men. Barghouti is very matter-of-fact, and seems almost resigned to it, with a controlled disdain, as when he says, while waiting to cross the bridge, "Nature had colluded with Israel in stealing the waters of the Jordan River."

Barghouti's poetic talents are evident in the book, as his style of writing throughout is very lyrical. He talks about the many hotel rooms he stayed in as a result of different circumstances in his life. But he is very vague about what brought him there, and he doesn't really say what he was doing for the last thirty years, as if he assumes the reader knows already, or it isn't important enough to mention. It makes the reader curious to know why he moved around so much, but this curiosity is not satisfied and the reader is still left wondering after finishing the book. He goes on to say that many people would have hated to stay in so many hotel rooms, but he reflects that in a way it was good. He is not attached to anything in them, nothing is his, so when it is time to leave, as is inevitable, it is easier. This Bedouin life of his, without doubt, is another consequence of his dispossession.

Memories of his older brother, Mounif, haunt him from the very beginning. We are not told the details until the end, but the reader is keenly aware of some tragedy surrounding Mounif. No matter where he is, there is always some reminder of his older brother, giving the book a 
sorrowful cloud of mourning that is ever present. When, at the end, the circumstances of Mounif's tragic death are revealed, it is as if the details were forced out of him, too painful to bear, but something that must be done to complete the book. The melancholic tone of the book comes through with Barghouti's account of the special meanings contained in a prosaic event like the ringing of the telephone, which is greeted with a mixture of anxiety and excitement. The latter is because it could be a family member that had not called in a while, the former because it could be bringing bad news, as when he was told about the deaths of both his father and his brother.

But there are also happy memories in other parts of the book, like the time he won first prize in a literary competition and was awarded a beautiful tea set made of fine china, which his uncle helped him carry in the rain to his house. It was common for the uncle to visit their house, and on one such day, Barghouti's mother had some guests over and served them tea in the precious tea set. When tea was passed to the uncle, he refused it, saying that he only carried it on his back, in the rain, and he did not deserve it, and the everyday glass cups were good enough for him!

The book is dotted with important figures. Some are well known, like Mahmoud Darwish, a prominent Palestinian poet, Naji al Ali, a well-known Palestinian cartoonist, assassinated in 1987, and Ghassan Kanafani, a respected Palestinian writer, assassinated in 1972. Others were famous once and forgotten, like Umm Khalil, the only person, and a woman at that, to run against Yasser Arafat for the Presidency of the Palestinian Authority.

I thoroughly enjoyed reading this book. The narrative style makes it an easy read and the openness in which it is written is quite touching. The reader is flooded with charming stories of people found only in small villages, surrounded by figs and olives, that bring out the rich culture, folklore and verbal expressions of the Palestinian people. It also displays Ramallah in the eyes of a native who has not seen it in thirty years. For someone who has not been to Ramallah, this is a good way to be introduced to it and learn about its charms and beauty, how it used to be and what it is now. For someone who has been there before, like myself for a visit, it explains things I did not appreciate and reminds me of things I loved. Like Barghouti, Palestine became precious to me, as he so eloquently describes, because I did not have it. I was indeed one of those Palestinian women he talks about who wore a golden map of Palestine in a chain around my neck.

This is a different book about displacement because the author describes 
how displacement has affected every part of his life, including indirectly determining the size of his family. Displacement also made him appreciate the little things in life, like a bottle of olive oil. This resonated with me, because every time I see an olive tree, my thoughts always tum to the olive tree in my family's house in my hometown in Palestine. It is also very important to Barghouti that his son, Tamim, sees this land one day. One of the first things he does when he arrives in Ramallah is to start the procedures for getting his son his Palestinian papers. Barghouti does not want his son to go through what he himself went through, that is, waiting for thirty years to be allowed to enter because he did not have the necessary documents.

In I saw Ramallah, Barghouti talks about the time he and some friends and family were traveling to Switzerland from France. As they waited to cross the border, the policeman asked for their passports. When he received all the passports, he realized that while most of them carried the same last name, no two passports were from the same country! The policeman was astonished, and started asking for an explanation, but then thought the better of it, since it would be too complicated, he was sure. As he let them go, someone quipped, "We really are a scandal." As I read that, I laughed wholeheartedly in recognition because I could hear the Arabic phrase reverberating in my head. Then it suddenly struck me, that this is the epitome of displacement. 